\title{
The 1982 Department of Justice Merger Guidelines: An Economic Assessment
}

\author{
Janusz A. Ordover $\dagger$ \\ Robert D. Willigł
}

Well before the new Merger Guidelines were issued in June 1982, it had become commonplace to criticize the reigning 1968 Guidelines as significantly out of touch with the new learning in industrial economics. In the intervening years, students of empirical industrial economics had argued that the market share increments that were likely to be challenged - for example, a horizontal inerger of two firms each with a 5\% inarket share-were not likely to enhance substantially the market power of the merger partners. Neither was the resulting increase in concentration likely to worsen inarket performance appreciably. Other empirical arguments suggested that inarkets in which four firms held a 75\% market share, "highly concentrated markets" in the language of the 1968 Guidelines, were not always susceptible to collusion and that the incumbent firms might be expected to behave as rivals, if not necessarily as competitors. Furthermore, theoretical work im industrial organization showed that vertical mergers were less likely to cause resource misallocation than was feared by the drafters of the 1968 Guidelines. In fact, a substantial consensus emerged that vertical mergers were as likely to promote efficient allocation of resources as not.

The 1982 Merger Guidelines were expected to close the gap between this new learning and the enforcement of the merger statutes. Not surprisingly, the new Guidelines: (1) increase the market share levels of the inerging firms at which a merger will presumptively go unchallenged; (2) significantly raise the benchmark levels for classifying markets as concentrated and highly concentrated; and (3) markedly restrict the universe of vertical mergers that are likely to be challenged. Surprismgly, however, the Guidelines also provide a novel way of con-

$\dagger$ Professor of Economies, New York University; Adjunct Professor of Law, Columbia University.

‡ Professor of Economics and Public Affairs, Princeton University.

We would like to thank Eleanor Fox for comments and efforts that were exceedingly helpful and well beyond the call of duty. She cannot be blamed, however, for the result. We would also hike to thank the National Science Foundation for support. 
structing the relevant product and geographic inarket for the purpose of evaluating the likely effects of an acquisition or a merger. Furthermore, sharply breaking with tradition, the Guidelines measure concentration using the Herfindahl-Hirschman lndex (HHI) in place of two-, four-, and eight-firm concentration ratios (CR2, CR4, and CR8, respectively).

In this Article, we survey the new Guidelines froin the vantage point of the economic theory of industrial organization. We focus on the question of whether the Guidelines will accurately identify those inergers likely to have anticompetitive effects. Our goals are to expose the conceptual foundations that underlie the Guidelines, to illustrate and clarify the Guidelines' usefulness in merger analysis, and to suggest soine of their weaknesses in light of the nost recent advances in industrial organization economics.

In Part I, we discuss the Guidelines' general methodology for establishimg the relevant product and geographic market. We find this inethodology consistent with, and considerably more practical than, the theoretical economic analysis of horizontal inergers. In Part II, we atteinpt to clarify geographic market definition and analysis of concentration, because we feel that the Guidelines delineate a highly desirable approach in a soinewhat cryptic manner. In Part III, we address the Guidelines' approach toward assessing the effects of a horizontal 1nerger withm the relevant inarket. Again, we find inuch consistency with economic learning, but we also identify important weaknesses in the Guidelines' handling of potential entry and firm conduct. Finally, in Part IV, we state our view that the economics literature has recently formulated a perspective on vertical mergers that the Guidelines overlook, and that the Guidelines could be improved in this area.

I

Market Definition: A First Step in Merger

ANALYSIS

\section{A. An Economic Analysis of Mergers}

Froin the perspective of pure theoretical economics, the concern of antitrust analysts with matters of market definition has always seemed misplaced. Arguments for and against a inerger that turned upon distinctions between broad and narrow inarket definitions have always seemed theologic rather than econonic. The focus on market definition lias seeined to be an inadequate substitute for, and a diversion froin, sound direct assessinent of a inerger's effects.

A theoretical economic analysis of a lorizontal inerger need never include the step of determining a relevant market. Instead, the focus 
would be placed on the assets combined by the inerger, on the crosselasticity of demand for the products produced by those assets, and on the preinerger and postmerger total own-price elasticity of demand for those products, which is the price elasticity of demand facing the firm. ${ }^{1}$ In these terms, a horizontal merger will raise prices (relative to costs) to the extent that it lowers the own-price elasticity of demand for the affected products, thereby reducing the loss in sales volume caused by a given price increase.

A horizontal merger can make demand more inelastic in several ways. First, the nerged firm can internalize demand shifts between the merging firms' products that are induced by price rises and that served, before the merger, as constraints on the abilities of the merging firms to elevate prices. Thus, the merged firm may have incentives to raise prices because diversion of sales is less of a threat, inasmuch as the diversion is to another of its own products. Second, the merger partners can coordinate the production and pricing of their products, thereby replacing any premerger competition with cooperation. Third, the supply and pricing decisions of the merging firms' active and potential rivals might becoine less competitive because of the rivals' perceptions of the inerged firm's new strategic position. On the other hand, these anticompetitive effects of a horizontal inerger may be inconsequential or nonexistent if the own-price elasticity of demand after the merger is sufficiently large because of the availability of close substitute products, the vigorous competition of rivals, or by the force of potential supply and entry.

\section{B. Market Definition in the Guidelines}

\section{Methodology}

The essence of the Guidelines' framework is its definition of a market as "consist[ing] of a group of products and an associated geographic area such that (in the absence of new entry) a hypothetical, unregulated firm that made all the sales of those products in that area could increase its profits through a small but significant and non-transitory increase in price (above prevailing or likely future levels)."2 Thus,

1. This total own-price elasticity, referred to in economic jargon as the reduced-form demand elasticity facing the firm, measures the effects of price changes on the quantity demanded, with all responses by consumers, rival firms, and potential suppliers and entrants accounted for. Thus, this elasticity incorporates, among others, rivals' supply elasticities. Where firms decide on quantities produced rather than on prices, as in an industry that supplies a lomogeneous product, the construct measures the effects of quantity changes on price.

2. U.S. Dep't of Justice, Merger Guidelines \& II n.6, 47 Fed. Reg. 28,493, 28,494 n.6 (1982), reprinted in 71 CALIF. L. REv. 649, $650 \mathrm{n} .6$ (1983) [hereinafter cited without cross-reference as Guidelines]. 
by this definition, the firms operating in a relevant inarket could exercise inarket power by profitably elevating price if they were to coordinate their decisions in a cartellike inanner.

Obviously, which grouping of firms or products constitutes such a relevant inarket depends on the price increase that the hypothetical cartel is supposed to attain and maintain. The Guidelines stipulate that a provisional market is too narrow if a nontransitory $5 \%$ increase in the prices of products inside the inarket would significantly divert custoiner deinand within one year to products outside the market. ${ }^{3}$ Then, the relevant market will be broadened to include soine of these products, in the order of their substitutability, ${ }^{4}$ until and no further ${ }^{5}$ than the point where a hypothetical cartel could profitably elevate product prices inside the market by $5 \%$.

If the merging firms are in the same product and associated geographic inarket, ${ }^{6}$ the Guidelines will consider the merger horizontal. Thus, for the analysis of a horizontal inerger, a relevant inarket is a group of sellers that includes the inerging firms, where: (1) a hypothetical cartelization of the group could profitably elevate prices; and (2) the reinainder of the group could not profitably elevate prices upon the exclusion of either the sellers of any of the products represented in the group, or the sellers in any of the geographic regions represented in the group.

There may be more than one relevant market in which to assess a given inerger, and to avoid challenge a inerger must appear to be free of anticounpetitive effects in each. In determining whether to challenge a horizontal inerger, the Justice Departinent will assess the merger's effects by analyzing concentration, inarket shares, and other factors relevant to each market that includes both of the merging firms.

To illustrate this process of market definition, nnagine that a national manufacturer of chocolate-covered cherries, Chock-Cheri, Inc., wants to acquire a national inanufacturer of chocolate-covered peanuts, Tasty, Inc. There are inany product groups that include the output of these two firms and that are potentially relevant inarkets, e.g., candy, chocolate candy, chocolate-covered edibles, and food and drink sold at theaters. Candy would be too broad to serve as a relevant market if producers of a subset of types of candy could, by agreeinent, profitably elevate prices. Chocolate-covered edibles would be too narrow to serve as a relevant inarket if a hypothetical cartel would lose too many sales to other candies to inake a $5 \%$ price increase profitable.

3. Id. $\S \mathrm{II}(\mathrm{A}), 47$ Fed. Reg. at 28,494-95, 71 CALIF. L. Rev. at 651 .

4. Id. § II(A) n.12, 47 Fed. Reg. at 28,495 n.12, 71 CALIF. L. Rev, at 651 n.12.

5. Id. $\S \mathrm{II}(\mathrm{A}) \mathrm{n} .11,47 \mathrm{Fed}$. Reg. at $28,495 \mathrm{n} .11,71$ CALIF. L. Rev. at $651 \mathrm{n} .11$.

6. Id. $\S \mathrm{III}, 47 \mathrm{Fed}$. Reg. at $28,496,71$ CALIF. L. Rev. at 655. 
Chocolate candy would be a relevant market if all chocolate candy producers could profitably elevate prices by agreement, but could not do so without the participation of all subgroups, such as sellers of chocolate-covered nuts and fruits. In addition, goods sold at theaters could define another relevant market with a different group of firms that included popcoru sellers and did not, by description, include firms that sell chocolates only through specialty retail outlets. ${ }^{7}$

\section{The Guidelines and Economic Analysis \\ a. A Useful Forensic Framework}

The 1982 Merger Guidelines provide a conceptual framework for horizontal merger analysis that is largely consistent with the perspectives of theoretical economics. Indeed, the noteworthy intellectual feat of the Guidelines' authors is the creation of a forensically useful framework that embodies nuch of the best available economic learning. The frainework's centerpiece is its narket definition methodology. Far from a theologic diversion, this process of determining the relevant narket will effectively chamiel attention and promote appropriate economic analysis.

The usefulness of the Guidelines' framework is shown by reference to the concept of total own-price elasticity of demand. As described in Section A, a merger's effects could be assessed in terms of econoinic theory by determining whether the merger appreciably lowers the total own-price elasticity of demand for the affected products. This ineasure of the loss in sales that results from price increases can be disaggregated into the portions that are diverted to various categories of other products. Froin this viewpoint, in principle, the Guidelines draw the boundaries of a relevant inarket just widely enough that the diversion of sales to products outside would permit profitable coordinated elevation of prices inside the market by $5 \%$. Then, the question whether the inerger would actually raise prices reduces to the question of the extent to which price increases by the nerger partners would divert their sales to other firms or products inside the relevant inarket. In this way, the Guidelines standardize market definition as the first step in merger analysis so that the subsequent steps can focus on effects that occur within the inarket. This market definition process succeeds in decoinposing merger analysis into steps that are each inore manage-

7. It is important to note, however, that market shares for the firms in this relevant market must be calculated on the basis of all their sales, not just sales at theaters, unless their sales at theaters are made at special wholesale prices. See id. \& II(A) \& n.14, 47 Fed. Reg. at 28,495 \& n.14, 71 CALIF. L. REv. at 652 \& n.14 ("If . . . price discrimmation is possible, the Department will consider defining additional, narrower relevant product markets oriented to the buyer groups subject to the exercise of market power."). 
able, that each relate to forensic custom, and that, as a whole, implement many of the lessons of economic theory.

\section{b. The 5\% Test}

The Guidelines provide no justification for the proposed 5\% figure. Perhaps this is because the figure is not intended to be inflexible, even in principle. ${ }^{8}$ Although literal mterpretation of the 5\% threshold might lead to an excessively narrow market definition in some circumstances, this is initigated by the stipulation that "the Departinent will not exclude any product that is at least as good a substitute as any product included." 9

Moreover, from an economic standpoint, it is not necessarily relevant to ask whether a cartel could induce a price increase of any particular percentage. A $5 \%$ price increase may result im almost no social welfare loss (as measured by total real income, includimg consumer surplus and profits) in soine inarkets, while inducing a substantial loss im other markets. The size of the loss is directly related to the value of market sales, to the elasticity of market demand, and to the preexisting percentage difference between price and marginal cost. However, while considerations of this kind are germane to a detailed cost-benefit analysis that weighs the social losses from any diminution of competition against efficiency gains, it seems appropriate to focus upon price changes when defining markets in a set of guidelines that must be less detailed. Therefore, "we will not concern ourselves here with the concept and the size of the percentage threshold.

\section{c. One Inconsistency with Economics}

There is one type of situation in which the Guidelines' conceptual frainework is meonsistent with the perspective of theoretical economics. A relevant inarket must make business sense in that it must mclude products with enough coinpetitive interaction that firms in a successful cartel would have to coordinate all of their prices. These products may be consuiner goods, basic resources, or intermediate goods or services at any level of a vertical chain of production. The Guidelimes, however, can establish relevant markets that make no business sense, most glarmgly in this latter case, by excluding consideration of potential entry in assessing the profitability of price increases by the hypothetical

8. Id. § II(A), 47 Fed. Reg. at 28,495, 71 CALIF. L. REv. at 651 ("As a first approximation, the Department will hypothesize a price increase of five percent and ask how many buyers would be likely to shift to the other products within one year. The Department will continue expanding the provisional market until it satisfies the general profitabihity standard stated above." (footnotes omitted)). See also id. n.10, 47 . Fed. Reg. at 28,495 n.10, 71 CALIF. L. REv. at 651 n.10.

9. Id. $\S \mathrm{II}(\mathrm{A})$ n.12, 47 Fed. Reg. at 28,495 n.12, 71 CALIF. L. Rev. at 651 n.12. 
cartel. ${ }^{10}$

For example, imagme that National Nail, which produces and packages nails, merges with General Hardware Distribution, which packages and distributes nails, screws, wire, and other hardware. Under the Guidelines, firms that package nails would make up a relevant market if purchasers would not substitute screws, rivets, or unpackaged nails in response to a $5 \%$ increase in the price of packaged nails. Then, the merger could be viewed in part as horizontal, even though it might have been the case that the overlapping activity of packaging nails provided relatively little value added, required no specialized assets, and was not subject to significant economies of scale. Yet these facts would imply that nail packaging is an insubstantial stage of production in both the business and economic senses.

Fortunately, the merger between National Nail and General Hardware Distribution would not be challenged under the Guidelines. On the above-inentioned facts, virtually any entrepreneur, and especially other nail manufacturers and other hardware distributors, could package nails. And the Guidelines state plainly: "If entry into a market is so easy that existing conpetitors could not succeed in raising price for any significant period of time, the Department is unlikely to challenge mergers in that market."11

The point remams, however, that the Guidelines can define as relevant markets product groupings that are irrelevant to both economic and busmess analysis because of ease of entry. Such anoinaties could have been avoided by including in the definition of relevant markets the constraints on price elevation that arise from potential entry.

\section{Subjective Factors in Market Definition}

The Guidelines do not remove all foibles and elements of subjectivity from the market definition process. This is the case for several reasons. First and most obviously, the needed fine-grained demand data may be unavailable to perform rigorously the $5 \%$ tests of sales diversion called for by the Guidelines. Then, the analyst will have to rely on less precise criteria such as those set forth in the Guidelines. ${ }^{12}$

Second, the outcome of a 5\% test of sales diversion is sensitive to assumptions concerning the behavior of the firms outside the provi-

10. Id. § II n.6, 47 Fed. Reg. at 28,494 n.6, 71 CALIF. L. Rev. at 650 n.6.

1I. Id. \& III(B), 47 Fed. Reg. at 28,498, 71 CaLIF. L. Rev. at 657.

12. Id. \& II(A), 47 Fed. Reg. at 28,495, 71 CALIF. L. Rev. at 651 . See also Edwards, Joffe, Kolasky, McGowan, Mendez-Penate, Ordover, Proger, Solomon \& Toepke, Proposed Revision of the Justice Department's Merger Guidelines, 81 CoLUM. L. REv. 1543, 1556-60 (1981); U.S. v. E.I. du Pont de Nemonrs \& Co., 351 U.S. 377 (1956); Brown Shoe v. United States, 370 U.S. 294 (1962). 
sional market. An assumption that the excluded firms would accommodate the efforts of the hypothetical cartel to raise prices would yield the smallest possible market and encourage challenge of a merger. Conversely, less intervention would be associated with a presumption of nonaccommodating behavior, since such an assumption yields nore broadly defined markets.

The importance of this behavioral dimension can be shown by an example. Assuine that three gas stations are located along North-South Avenue. These stations compete on price at the puinp. Each station has certain locational advantages, in the sense that some of its customers prefer it to the other two gas stations. Prior to the inerger, a pricing equilibrium has been reached, perhaps at levels above inarginal costs, but not substantially so. The important feature of this equilibrium is that none of the three firms by itself can raise its price without losing profits.

Assume now that $\mathrm{A}$ and $\mathrm{C}$, who are located on either side of $\mathrm{B}$, want to inerge. Can they profitably raise their price by $5 \%$ ? The answer is "No" if B does not go along. The reason is that if A raises his price, soine of his customers will leave for $B$, but none of his customers will venture to $C$. His merging partner $C$ faces the saine predicainent. In the postulated scenario, the analyst might conclude that the inerger is non-horizontal because $\mathrm{A}$ and $\mathrm{B}$ do not need the cooperation of $\mathrm{C}$ to raise their prices profitably, and $\mathrm{C}$ and $\mathrm{B}$ do not need the cooperation of $A$ to raise their prices. Yet such a conclusion is likely to be incorrect. The analyst inust inquire whether $B$ is likely to maintain his price, or whether he is likely to take advantage of A's and C's efforts and raise his price as well. If the latter is true, then according to this imquiry, the merger can lead to a price increase, even though a inore simple-mimded approach might produce a different conclusion. While this example is broadly drawn, it may be relevant to the analysis of geographic markets and of markets where differentiated products have localized rivals.

In any case, it is always true that behavioral considerations cannot be avoided when performing the 5\% sales diversion test. In asking whether a hypothetical cartel could raise a price by the hypothesized $5 \%$, it is also necessary to ask, "Under what assumptions regarding the behavior of the firms which are not the cartel ineinbers could the price rise occur?" In some circumstances, this question is amenable to economic analysis. For example, nonaccommodating behavior is certainly more likely, if expansion is less costly for the other firms, and if less commitment is required of them. Behavioral history may also be relevant evidence on this poimt.

Third, the 5\% test inay lead to the lenient treatınent of nergers in niarkets subject to substantial preinerger coordination. For example, 
consider a merger of two firms im a perfectly cartelized broccoli market in which all broccoli manufacturers liave already established output levels such that the resulting price maximizes their joimt profits. In such a case, a 5\% price imcrease would not be profitable-if it were, the initial price would have been $5 \%$ higher. Hence, it follows from the Guidelines that the relevant market for merger assessment must extend beyond broccoli to, perhaps, all green vegetables.

Even though this merger could not raise price above the preexisting cartel level, allowing the merger to remaim unchallenged may not be a desirable solution in view of the concern that increased concentration stabilizes noncompetitive behavior in markets that already do not function well. Perhaps this inerger would be handled under the proviso that the Department is inore likely to challenge mergers in markets that are already performing noncompetitively. ${ }^{13}$ It is not clear, however, how much weight the Department will put on the various qualitative indicia of noncompetitive behavior, as opposed to an apparent quantitative finding that the firms im a hypothesized market cannot pass the $5 \%$ test, or that there is a demonstrably low degree of concentration in the expanded market.

\section{II}

\section{GeOGRAPHIC MARKET Definition}

From the standpoint of econounic analysis, the distinction between product and geographic markets is not particularly useful. Whether one searches for a definition of the relevant product or geographic market, one's first concern is identifying firms or products that can constrain the ability of the merging firms to increase price after the inerger. ${ }^{14}$

The Guidelines do not make an analytic distinction between geographic and product market definition. Thus, they correctly apply the same general methodology to both market definition issues. However, they also proceed from an initial assumption that postmerger price discrimination will be impossible, without providing a clear indication of why price discrimination should make a difference in the analysis. In this Part we examine the significance and implications of this assump-

13. Guidelines \& III(C)(4), 47 Fed. Reg. at 28,499, 71 CAlif. L. Rev. at 659 .

14. Id. $\S \mathrm{II}(\mathrm{C}), 47 \mathrm{Fed}$. Reg. at $28,496,71$ CALIF. L. Rev. at 653 . Thus, for example, the ability of a brewery in Oregon to raise the price of its beer may be constrained not only by the availability and prices of different alcohohic and nonalcoholic drinks, but also by the availability of beer produced elsewhere. If so, beer imported into Oregon can be treated as another substitute product that is available to Oregon beer drinkers. It need not be a perfect substitute for the Oregon-brewed beer (perhaps because of taste differences or because imported beer is priced more dearly due to transportation costs), but it is surely likely to be a constraining factor on the ability of the Oregon brewer to raise prices. 
tion. We also identify some minor technical defects in the Guidehnes' approach to geographic substitutability.

\section{A. Absence of Postmerger Price Discrimination}

In determining the boundaries of a market, the Guidelines initially assume that price discrimination between geographic areas is impossible. ${ }^{15}$ Based on this assumption, this Section shows that a geographic market can be no smaller than the area in which the prices of a merging firm (or hypothetical cartel) are uniform. It then shows that if there are iniports into the area from another region in which an equal price must prevail, the firm or cartel must be able to raise prices profitably in both the importing region and the exporting region in order to exercise market power. The geographic market must mclude the exportimg region if the participation of the exporters is needcd to accomphish this price increase. ${ }^{16}$

Assume that in the United States for example, the proverbial widget is produced by a number of firms. Two of these firms-Widgets Inc. (WINC) and Widgets and Accessories Corp. (WAC)-plan to merge. Assume also that WINC sells its widgets at uniform prices (net of transportation costs) throughout the United States. This means that as far as WINC's products are concerned, the relevant geographic market under the Guidelines' analysis is no smaller than the United States, provided that after the merger, spatial price discrimination does not becoine possible. The fundamental reason is that, absent postmerger price discrimination, WINC cannot selectively raise prices im any portion of the United States. Consequently, any firm that produces and sells a competimg product anywhere within the United States constrams WINC's power to elevate prices throughout the country.

The Guidelines caution that such a provisional market may be too small for the purpose of assessing the possible anticompetitive effects of a merger if: (1) there are imports into the area from productive facilities located outside of the provisional geographic market; (2) imports could be triggered by a small nontransitory price increase in the area; or (3) the geographic area im which the hypothetical cartel makes its sales were to shrink as a result of such a small nontransitory price increase. ${ }^{17}$ Therefore, it is necessary to examine how the presence of imports affects the construction of geographic markets.

To this end, we complicate our widget example and postulate that imported Japanese widgets compete in the United States with domesti-

15. Id., 47 Fed. Reg. at 28,496, 71 CALIF. L. Rev. at 654.

16. If it cannot be shown that this will occur, the provisional market must be expanded. Id., 47 Fed. Reg. at 28,496, 71 CALlF. L. Rev. 653-54.

17. Id. $\S \mathrm{II}(\mathrm{C})$ \& n.21, 47 Fed. Reg. at 28,496 \& n.21, 71 CALIF. L. Rev. at 653 \& n.21. 
cally manufactured widgets. We assume that there are no trade barriers and that widgets sell in Japan for a price equal to the United States price, less the transportation cost. In other words, there is no imternational price discrimination. This means that arbitrage ${ }^{18}$ between the United States and Japan would render ineffective any attempt to drive a wedge between net widget prices prevailing here and in Japan.

This does not imply, however, that arbitrage could undo a uniform mcrease in prices here and abroad. If WINC and WAC had sufficient market power to be able to raise the price throughout the geographic area in which price discrimination is not feasible, arbitrageurs would be unable to prevent the two firms from exercising that power.

Given that there is no spatial price discrimination between the Umited States and Japan, it is important to determine whether the United States and Japan together constitute a geographic nrarket for widgets. This determination will influence the calculated market shares of the merging firms (WINC and WAC). It is possible that a cartel composed solely of American widget inanufacturers could effectively and profitably increase widget prices by $5 \%$ here and abroad by constricting its United States output. Even though imports would be stimulated, they would not necessarily increase enough to make the price increase unprofitable. Hence, a coordinated use of the productive assets of American producers might be sufficient to induce a threshold price increase, even if Japanese producers behaved like a competitive fringe in the United States market and were also perfect competitors in Japan.

By application of the 5\% test in this case, the United States would constitute the relevant geographic market because by constricting the output of the widget plants located in the United States, the cartel could profitably effect a small but significant $5 \%$ nontransitory price increase without stimulating a volume of imports that would make the increase unprofitable. Here, it seems, the Guidelines mandate that market shares be calculated on the basis of sales, or capacity, of only the plants located in the United States. Imports would be excluded from the base on which the shares of U.S. firns were measured. ${ }^{19}$

18. Arbitrage involves the purchasing of goods in one market for resale in another market for the purpose of takiug advantage of a price differential between the two markets.

19. The Guidelines define a geographic market as an area derived from the location of sellers' facilities. Where United States firms could alone raise prices by coordinating, the Uuited States would be the relevant geographic market, and the output of foreign firms would be excluded. Id. \& II(C), 47 Fed. Reg. at 28,496, 71 CALIF. L. REv. at 653 . On the other hand, soine ambiguity remains on the imterpretation of the Guidelines im this regard, in view of footnote 24. This would suggest that all of Japan be included in the geographic market masmuch as Japauese widgets are viewed as perfect substitutes for American widgets in the eyes of United States buyers. See id. n.24, 47 Fed. Reg. at 28,496 n.24, 71 Calif. L. Rev. at 654 n.24. This inclusion seems to 
The Department of Justice warns that smce the Guidelines' geographic market is an area derived from the locations of sellers' facihties, it may differ from the traditionally defined geographic market, which was based on buyer locations. ${ }^{20}$ However, it seems that the Department would be willing to consider geographic markets oriented to buyer locations, where price discrimination is feasible. ${ }^{21}$ Thus, in our example, Japanese imports could be included in the United States geographic market if their net price could differ from that charged im Japan by their producers.

Absent geographic price discrimination, hovrever, the Guidelines would either limit the market to United States plants or, alternatively, widen the market to mclude Japanese plants. In the latter case, market shares would be based on the entire output or capacity of United States and Japanese plants, not just on their sales to American buyers. The wider market definition would be appropriate under the Guidelines if the United States firms alone could not mcrease price. In addition, the United States alone would be too narrow as a geographic market if imports accounted for more than just a small share of total United States sales. ${ }^{22}$

Thus, $\dot{n} 1$ the absence of price discrimination, the Guidelines seem to rule out the middle ground of calculatimg the market shares of domestic merger partners on the basis of total domestic sales, mcludimg imports. We do not find this position persuasive. Instead, where United States firms together could increase prices, but where there are imports that are close substitutes, we suggest that market shares be calculated on the basis of actual sales or usable capacity for the firms whose productive capacity supplies the U.S. market. The relevant shares of Japanese firms would be calculated on the basis of their actual sales into the American market or, if the relevant data could be generated, on the basis of projected sales with a $5 \%$ price increase.

The rationale for this position is that existing and potential imports offer competitive restraint to United States firms'that can be assessed independently of consideration of their geographic origm. For example, under the hypothesis that imports imstead origmated from a domestic firm that exhibited the same supply responsiveness as the actual importers, both the Guidelines and economic analysis would agree on the inclusion of the hypothesized firm in the relevant geographic market. Thus, neglecting imports solely on the basis of their geo-

be suggested notwithstanding a finding that a cartel comprised of only American firms could profitably raise price.

20. Id. n.21, 47 Fed. Reg. at 28,496 n.21, 71 CALIF. L. Rev. at 653 n.21.

21. Id. $\$ \mathrm{II}(\mathrm{C}), 47$ Fed. Reg. at $28,496,71$ CALIF. L. Rev. at 654.

22. Id. n.21, 47 Fed. Reg. at 28,496 n.21, 71 CALIF. L. Rev. at 653 n.21. 
graphic origin can significantly overstate the anticompetitive effects of domestic mergers.

Under the Guidelines, the Umited States and Japan need not constitute a single geographic inarket simply because net prices of widgets are equal in Japan and in the United States, and Japanese widget manufacturers compete in the United States. As we have demonstrated, the United States alone can be a relevant geographic market if the supply of widgets from Japan to the United States is sufficiently small relative to total United States demand and is not significantly responsive to small nontransitory price increases in the United States. This supply inelasticity may exist because marginal production costs in Japan rise rapidly with the quantity of output produced and Japanese consumers have a highly inelastic demand for the exportable product. Thus, despite the presence of Japanese imports, coordinated constriction of output by U.S. firms could profitably increase price, and the products sold or produced in the United States alone would constitute a relevant market.

Soine analysts would conclude that because widget prices are equal in Japan and in the United States and because importers make sales in the United States, the markets should be international in scope. ${ }^{23}$ Thus, Landes and Posner, upon examining a model analogous to the one underlying our example, conclude that if importers make any significant sales in the importing country, all of their production capacity should be included in the market. ${ }^{24}$ We think that the approach adopted in the Guidelines is preferable because it is more sensitive to the actual strength of the competitive constraint exercised by productive capacity that is located outside of the provisional market. When the output of that productive capacity can be easily diverted to serve the consumers in that area, the provisional market is defined too narrowly. It must be expanded, therefore, to include all of the productive capacity that constrains the market power of the hypothetical cartel. ${ }^{25}$ On the other hand, if the productive capacity diverted is insufficient to prevent a sustainable price increase in the provisional

23. We are fully aware that the Guidelines make a substantial, though undefined, qualification for foreign competition. See id. $\$$ II(C), 47 Fed. Reg. at 28,496, 71 CALIF. L. REv. at 654 ("The Department . . . will be somewhat more cautious, both im expanding market boundaries beyond the Urited States and in assessing the likely supply response of specific foreign firms."). Thus, no special significance should be attached to our use of international trade in the examples developed in the text.

24. See Landes \& Posner, Market Power in Antitrust Cases, 94 Harv. L. Rev. 937, 963-72 (1981). For a discussion of the model, see also Ordover \& Willig, Market Power and Market Definition, at 23-35 (July 9, 1981) (memorandum to ABA Section 7 Clayton Act Committee), in Background Papers Re: Merger Guidelines (S. Edwards coord. n.d.). Cf. Brennan, Mistaken Elasticities and Misleading Rules, 95 HARv. L. REv. 1849 (1982).

25. In our widget example, if the Japanese firms can cheaply expand their total output of the 
market, the provisional market should not be so expanded. ${ }^{26}$

In light of this discussion, it is apparent that debate over geographic market definition is relevant only msofar as it has implications for the market share calculations that are to serve as proxies for market power. ${ }^{27}$ Because they are only proxies for market power, market shares must be interpreted with caution. For example, a large market sliare may not imply substantial market power if it is held im a lighly elastic market. ${ }^{28}$ The algorithm developed im the Guidelines instructs the analyst to contract market shares by expanding the relevant geographic or product market until the demand elasticity facmg the firms in the market is low enough to make a threshold price mcrease of $5 \%$ profitable.

\section{B. Presence of Postmerger Price Discrimination}

The Guidelines' initial assumption of price discrimmation impossibility represents an interesting but unnecessary simplification of the analysis of market definition. As this Section shows, the standards for geographic market definition developed under this assumption do not change when price discrimination exists. This Section discusses the problems involved in determining when price discrimination is feasible, and then discusses the effect of price discrimination on the Guidelines' $5 \%$ test. It concludes by evaluating the strengths and weaknesses in the methods used by the Guidelines to construct geographic markets.

\section{Determining the Possibility of Spatial Price Discrimination}

Determining when price discrimination is possible requires identification of firms (or production facilities) whose presence in a hypothetical cartel is essential to accomplish the prescribed price increase. If a group of sellers can only achieve a discriminatory margin of less than $5 \%$ in soine regions, the cartel must include those additional firmsincluding arbitrageurs-whose participation in the cartel is required to accoinplisli the threslold price increase. Hence, under the Guidelimes' $5 \%$ test, a narrow area can constitute a geographic market if prices there can be elevated by $5 \%$ without simultaneous price increases elsewhere.

exportable commodity or easily divert a portion of their domestic sales to the United States market, it is possible that a broadly defined geographic market is warranted.

26. Guidelines $\$$ II(C), 47 Fed. Reg. at 28,496, 71 CALIF. L. REv. at 653-54.

27. The Guidelines define market power as the ability to increase price above marginal cost (so as to earn a supracompetitive rate of return). Id. \& I, 47 Fed. Reg. at 28,494, 71 CALIF. L. REv. at 650 .

28. It is shown in Ordover \& Willig, supra note 24 , that in a certain sense the narrowly defined "domestic" market is generally more elastic than a broadly defined "international" market. 
There are two forces that can render spatial price discrimination infeasible. Perhaps the most important constrainmg factor stems from the possibility of spatial arbitrage, or spatial divertibility of sales. When arbitrage is perfect, as it would be if arbitrageurs were to mcur only transportation costs, then sales destined for one geographic area would be diverted to another area as soon as any net price differential emerged. Thus, arbitrageurs who move the product around in search of the highest net price would be active competitors of the actual manufacturer of the product. They use the manufacturer's own product to compete away any monopoly profit that the manufacturer may try to extract through spatial price discrimmation. ${ }^{29}$ Because one unit of manufacturer's output (here, a widget) is a perfect substitute for another unit of his output (another widget), the relevant geographic market must mclude both the manufacturer and the arbitrageur as long as they are within the region subject to perfect arbitrage. ${ }^{30}$

Spatial discrimmation may also be difficult to implement when a seller's price is constrained at virtually eaclı location by alternatives available to local customers. Such alternatives might include customers' self-production, existing local firms, or the potential supply from new local firms. Although these alternatives may be less efficient in production than a large-scale manufacturer, they may avoid transportation costs, and inay thereby offer the manufacturer stiff competition at each purchase location.

\section{Similarity to Nondiscrimination Analysis}

We inust now examine the inodifications to the analysis that inay have to be made in the event that price discrimination is feasible. We argue that the possiblity of price discrimination does not necessitate any fundamental adjustments in the inethodology. The possibility of price discrimination means that arbitrage is imperfect, and prices can be increased in some geographic area (or to one group of consumers) without requiring that prices be increased elsewhere (or to other consumers). The key question is how far price discrimination can proceed without triggering arbitrage. In other words, the profitability of

29. Consumers act, of course, as arbitrageurs. For instance, shoppers may travel from one store to another in order to purchase a can of Star-Kist tuna at the lowest possible price. New Yorkers are prone to cross the Hudson to New Jersey not only to save sales taxes but also to avail themselves of generally lower prices. This movement of consumers narrows down any sustainable price differentials. It is commonly agreed that arbitrage is most developed in financial and foreign exchange markets where "transportation" costs approximate the price of a telephone call.

30. This same argument apphies to nonspatial price discrimmation. To illustrate, assume that WINC sells widgets to lawyers and economists. Assume the economists pay a lower unit price. Then, if lawyers can pretend to be economists, they will undo any cross-occupational price discrimination. Alternatively, economists could transship their wares (widgets) to lawyers and render ineffective WINC's discrimimatory practices. 
selective price increases depends upon how well arbitrage can be prevented. Thus, in some instances, arbitrage nay become feasible if the price differential between two geographic areas reaches $1 \%$. In other situations, however, $5 \%$ to $10 \%$ price margins may not imduce any arbitrage. In the former case, products produced by a plant and destined for different geographic areas are excellent substitutes for one another, and hence should be included in the same market. In the latter case, these products are not good substitutes, and may therefore be placed in separate markets.

This analysis can be clarified by considering a modified version of our widget example. Let us assume it likely that after the merger, net widget prices in Califorma could differ from those in Texas. ${ }^{31}$ To see why this does not necessarily mean that these areas constitute separate geographic markets, assume that widget manufacturers whose productive capacity is located in Texas could raise the price of widgets in Texas by $3 \%$ above the Califorma price by merging. Assume also that any additional price differential would make arbitrage between Cahforma and Texas feasible. Then, the Texas price could not be increased by $5 \%$ unless the Califormia price were simultaneously increased by $2 \%$, because only then could the $3 \%$ margm be maintained. Even then, any higher margin could not be sustamed because of the entry capabilities of the arbitrageurs.

But this implies that Texas alone would not be a relevant geographic inarket under the Guidelines because productive capacity supplymg Califormia would also exert a competitive constramt on the prices prevailing in Texas. As long as the Califorma suppliers kept their prices constant, Texas producers could not profit by raismg prices the full $5 \%$. Thus, the relevant geographic market must be widened beyond Texas. ${ }^{32}$

Another important instance of price discrimination arises when the exporter is "dumping" his products in the importing country. In our widget example, Japanese widget manufacturers might be selling widgets in the United States at a price below that of widgets im Japan. Such "dumping" can only occur when the exporting industry is imperfectly coinpetitive in its home market. We have elsewhere shown ${ }^{33}$ that such an imperfectly coinpetitive exporting industry might exercise a more effective constraimt on the domestic producers' pricing pohcies

31. Historical evidence of price discrimination may serve perhaps as a signal that postmerger discrimination is likely as well. In the absence of such evidence, the analyst may find it difficult to predict the likelihood and the extent of postmerger price discrimination. Furthermore, the Guidelines are silent on how this assessment will be undertaken.

32. Of course, this analysis would not apply if Texas manufacturers could successfully prevent arbitrage, even if the price margin exceeded the requisite $5 \%$.

33. See Ordover \& Willig, supra note 24. 
than it would if it were competitive at home with identical costs, because an imperfectly competitive export industry would export more at any given price than would a competitive industry. Consequently, the resulting equilibrium price in the importing country is likely to be lower if exporters were imperfect competitors at home than if they. were perfect competitors. ${ }^{34}$

In addition, it is quite likely that the elasticity of supply of exports of an imperfectly competitive export mdustry is higher than that of a competitive exporting industry. Hence, domestic producers in the importing country may find it more difficult to raise price when the exporting industry is imperfectly competitive in its home market than they would if the exporting industry were competitive there. In this case, at least, the presence of spatial price discrimination suggests that a broad rather than narrow geographic market definition may be more appropriate for assessing merger effects.

\section{The Guidelines' Approach to Substitutability}

Finally, some mimor shortcomings in the Guidelines' approach to geographic substitutability should be mentioned. First, because it is not always easy to apply the 5\% price increase test, the Guidelines provide some shortcuts to measuring geographic substitutability and to constructing geographic markets. ${ }^{35}$ While we have no difficulty with these shortcuts, we should nevertheless poimt out that observed "similarities or differences in the price movements" ${ }^{36}$ may not provide the necessary inforination for the assessment of substitutability. It is true that if widget prices move up and down together in the Umited States and in Japan, then an inference of a single geographic market may appear plausible. Yet such correlated price movements may be due to "global shocks" such as a worldwide increase in input prices or a worldwide fall in demand for the product in question. Such shocks have a tendency to affect prices similarly, even in independent geographic markets. Only if "local shocks" translate into correlated price movements may an inference of a single geographic market be drawn.

Second, the Guidelines have omitted from the list of factors relevant to geographic inarkets any mention of cross-shipments, or a coexistence of exports and imports of products im the same product category from a given geographic area. Cross-shipping can occur when either:

34. Our discussion assumed implicitly that importers behave like price takers in the foreign market. In the event that an importer las market power in the foreign market, it is perliaps likely he will have to be a part of the liypothetical cartel whose ability to increase prices by the threshold percentage is being tested.

35. Guidelines $\S \mathrm{II}(\mathrm{C}), 47 \mathrm{Fed}$. Reg. at 28,496, 71 CAlif. L. Rev. at 654.

36. $I d$. 
(1) the cross-shipped product is manufactured by noncompetitive industries in the two areas; or (2) the products belonging to the product category are not perfect substitutes.

To illustrate both situations, assume that widget manufacture in the United States and in Japan is oligopolized. Then, manufacturers in both countries may engage in "dumping" that leads to cross-shipping of widgets between the United States and Japan. Because a merger is likely to have greater adverse effects when it occurs in a nrarket that is already not functioning coinpetitively, the evidence of cross-shipping could be used as one of the factors that may be relevant in the assessnient of inerger effects in inoderately concentrated markets-i.e., markets in which the postinerger $\mathrm{HHl}$ is between 1000 and 1800 .

Now assume that Japanese consumers do not perceive American widgets to be perfect substitutes for Japanese widgets, and vice versa. Assuine also that tastes are variegatcd. Given these assumptions, widgets niay be cross-shipped when, for example, "snobs" in both countries prefer foreign widgets to doinestic widgets. When imports are not perfect substitutes for hoine goods, any presumption toward broad geographic market definition is, of course, weakened.

These omissions do not negate the fact that the Guidelimes provide a creative and economically valid approach to geographic market definition. In particular, the geographic market Guidelines are well integrated with the general inethodology for constructing markets in nierger analysis. In that respect, they are a substantial improvement over approaches that focus exclusively on the existing shipment patterns. ${ }^{37}$

\section{III \\ MARKet POWER}

After the relevant inarket has been defined in a horizontal inerger analysis, the next step is to assess the extent to which competition within the inarket would constrain the market power of the merged firm. At this stage of the analysis, coinpetitive restraint on the merger partners fron outside the defined market has already been accounted for in the determination of the inarket boundaries (with the exception of new entrants and shifts in supply that would take longer than six months). This restraint, however, is insufficient to stop firms within the inarket froin profitably raising prices were they to coordmate perfectly or to form a cartel. A reniaining question, then, is whether the merger would significantly facilitate such cartellike coordimation, or whether

37. See Elzinga \& Hogarty, The Problem of Geographic Market Delineation in Antimerger Suits, 18 ANTITRUST BULL. 45, 73-80 (1973). 
postmerger competition among the firms inside the market would instead deter the otherwise possible price increase.

Several factors are important $\mathrm{m}$ answering this question. It is a well-supported and generally accepted presumption that, other things being equal-or as economists are fond of saying, ceteris paribus -a firm has greater ability to exercise inarket power: (1) the larger its inarket share; and (2) the more concentrated the market. Market concentration facilitates the exercise of market power inasmuch as interfirm coordination is less difficult when there are fewer market participants and the pattern of market shares is more concentrated. Economists are also im agreement, however, that mergers in two distinct markets characterized by the same degree of concentration can produce quite different effects on market power. For example, market power is also dependent on entry barriers to the inarket. Indeed, if there are no entry barriers to the market, market power is not an issue at all because supracompetitive price increases are impossible.

Thus, while consideration of market concentration and market shares is an appropriate first step im the analysis of inerger effects, entry barriers play equally important roles. Other factors may also be relevant. In this Part, after setting out some general properties of mergers and summarizing the Guidelines' approach to assessing inarket power, we examine the factors affecting the ability to exercise market power.

\section{A. Economic Analysis of Horizontal Mergers}

Economic analysis of the effects of horizontal mergers requires that attention be focused on two of their generic properties that may lessen competition.

\section{Coordinated Use of Assets}

First, a merger generally permits coordinated use of productive assets that the merging firms independently controlled prior to the merger. These assets may include physical capital, organizational capital, patents, tradeinarks, teclinological know-how, and perhaps even market share. ${ }^{38}$ A merger thus consolidates the ownership and control of the assets, and inay augment market power as a result. Indeed, it is worth einphasizing that market power is always associated with the

38. The view that premerger market sliare is an asset implies that a subset of the firm's customers regards its product to be superior (at the going price) to the available alternatives. Then, a merger may enable this firm more profitably to exploit its captive customers if, for example, the less attached customers would divert their purcliases to the product(s) of the other merging firm in the event of a price increase. It is plausible to argue, lowever, that there must be a more fundanental underlymg asset (e.g., locational advantage) whicl creates such attachment between the supplier and its customers. 
ownership of soine tangible or intangible assets. In assessing a inerger's possible adverse consequences, the analyst should focus attention on the assets whose coordinated use is inade possible by the inerger. ${ }^{39}$ Consequently, if the inerger partners do not own any assets that are botli pertinent to the relevant inarket and not easily replicated by other firms-whether incumbent rivals or prospective entrants-then a merger cannot on this score augment the market power of the merger partners.

\section{Reduction in the Number of Firms}

The second generic characteristic of a horizontal merger is that, by reducing the number of independent decisionmaking entities, it inay facilitate a coordinated use of assets among the remaming firms, thereby diminishing competition. It has been well known since at least the nineteentli century ${ }^{40}$ that in an oligopolistic industry the equilibrium level of prices depends, ceteris paribus, on the degree of collusion or competition among the existing firms. The degree of rivalry may cover the whole spectrum from one extreine, where ohgopolists behave like perfect competitors, to the other exteine of full joint-profit inaximization, where they beliave like a cartel.

Economists have chosen a convenient behavioral benchmark to determine whether behavior is competitive or collusive. ${ }^{41}$ In the case of an oligopolistic industry that produces a lomogeneous product, that benchinark can be defined as follows. Assume that in choosing its production plan, an oligopolist takes as given the current production plans of his rivals. In other words, he selects that level of output that maximizes his current profit, under the proviso that his rivals' total level of output remains at its current level. If all firms behave in that fashion, then the firms are said neither to be competing nor colluding, but are considered to be behaving noncooperatively. In contrast, if a firm perceives that its rivals are going to expand their output in response to its contractions, it conjectures that the industry is rivalrous. Finally, if a

39. It is our view that such a focus on assets would help avoid some thereby obvious economic mistakes. For example, in a recent case, Federal Trade Commission lawyers argued that incumbent firms have an advantage over prospective entrants because the former already own trucks while the latter would have to obtain similar trucks. Plainly, in our economy, hittle if any market power can attach to the ownership of trucks which are easily bought and resold. Pre-Trial Brief, Gulf \& W. Indus., No. 9153, (FTC filed Aug. 27, 1982). This is not to deny that $m$ the United States, circa 1930, or elsewhere in the world today, a truck could be an asset to which monopoly power attaches. (We were employed by Gulf and Western as economic experts in this case.)

40. A. Cournot, Researches into the Mathematical Principles of the Theory of WEALTH (N. Bacon trans. 1963).

41. Fo: a more extensive and technical discussion see Ordover, Sykes \& Willig, Herfindahl Concentration, Rivalry and Mergers, 95 HARv. L. Rev. 1857 (1982). 
firm perceives that its rivals will contract their output when it contracts, or expand their output when it attempts to expand, it conjectures that rivals act cooperatively. ${ }^{42}$

\section{a. Market Thinning}

There are several ways that a reduction im the number of independent entities can facilitate coordination. First, where firms are charging supracompetitive prices, market thinning - the reduction in the number of active firms-is one likely cause of postmerger price increase and resource misallocation. Market thinning does not have anticompetitive effects in all markets. Thus, a horizontal merger that does not lower production costs will not tend to increase the equilibrium price if: (l) the industry is unprotected by entry barriers so that incumbents (existing firms) are fully constrained by prospective entrants; (2) incumbent firms are already maximizing joimt profits; or (3) the industry remains perfectly competitive.

\section{b. Reduced Strength of Competition}

Another possible effect of removing an active market participant through merger is the diminution in the strength of competition. The reduction in the competition's strength can be identified with changes in firms' conjectures about their rivals' responses to their output contractions. If, after the merger, each remaining firm beheves that its output cuts will not be undone by rivals' output expansions to the saine extent as was the case before the merger, then the firms will be more inclined to suppress output, thus elevating price. Alternatively, the merger may heighten firms' expectations that their output expansions will be met with pumishing concomitant expansions by rivals, with the same upward effect on price.

The view that a reduction in the number of firms facilitates coordinated use of assets among the imcumbent firms is a rock upon which much of industrial economics has been built. Consistent with this view is the economic theory underlying the Guidelines: that the main evil of horizontal mergers is their potential of facilitatimg ohgopohstic cooperation, leading to elevated prices and resource misallocation.

\section{B. The Guidelines' Approach}

The Guidelines strike a compromise between determining market power based on bright-line rules of quantitatively measured inarket

42. This analysis can be extended to oligopolistic markets with heterogeneous products and to monopolistically competitive markets. In these situations, the relevant behavioral beliefs pertain to price rather than to output responses of rivals. 
concentration and market shares and more vague weighings of other important factors. According to the Guidelines, horizontal mergers are unlikely to be challenged in markets where the postmerger HHI is below $1000 .{ }^{43}$ Where the postmerger HHI lies between 1000 and 1800, the likelihood that a merger will be challenged depends on the merging firms' market shares as indicated by the increase in the HHI, on the postmerger HHI, on the ease of entry, and on a variety of other factors that are indicative of the "ease and profitability of collusion." 44 Where the postmerger HHI exceeds 1800, inergers of significant size (causing the HHI to rise by 100 or inore) are likely to be challenged, while the factors mentioned above will be considered for smaller mergers. A inerger between a leading firm, one with a share of at least $35 \%$ and at least twice the size of the second largest firm in the market, and a firm with at least $1 \%$ of the market is likely to be challenged. Fimally, regardless of concentration, mergers are unlikely to be challenged in a market where entry is so easy that existing coinpetitors could not profitably raise price for a significant period of time.

In our view, these provisions of the Guidelines constitute a structure for analyzing the effects of horizontal inergers on market power that is adeptly formulated to be consistent with the lessons of economics. First, the threshold tests for market concentration and for entry barriers are in accord witl both economic theory and with conservation of judicial resources. Second, the HHI, although necessarily imperfect, is the best practical measure of market concentration that economists have developed to date. Third, it is consistent with economic logic that inergers be presumed to facilitate coordmation in markets above some level of concentration, regardless of the indicia of firm conduct. Fourth, economic learning makes it clear that in the midrange between a lack of concentration and near-monopolization a variety of factors other than concentration and market shares are critical im assessing the effects of horizontal mergers. Fifth, the Guidelines reflect the fact that economically ineaningful market shares cannot invariably be tabulated by arithmetic alone, without consideration of ambiguities in their measurement, in the umits frons which they are calculated, and in their coverage. We examine these propositions in inore detail im the next Section.

43. Guidelines § III(A)(1)(a), 47 Fed. Reg. at 28,497, 71 CALIF. L. REv. at 656.

44. Id. $\S \operatorname{III}(\mathrm{C}), 47 \mathrm{Fed}$. Reg. at 28,498, 71 CALIF. L. Rev. at 658. See also id. $\operatorname{III(A)(1)(b),}$ 47 Fed. Reg. 28,497, 71 CALIF. L. REV, at 656. 


\section{Factors Affecting Market Power}

\section{Market Concentration}

Consideration of market concentration must evidently play some role in analyzing whether the merger has imcreased the market power of the merging firms. If the merger partners were the only actual and potential participants in the relevant market, then the merger would have the effect of forming the very cartel whose existence was postulated in the market definition process. Thus, a finding that the relevant market before the merger is a duopoly protected by entry barriers must imply that the merger could significantly raise prices. ${ }^{45}$ Conversely, if the relevant market was highly unconcentrated after the merger, then it is implausible that the merger could diminish competition, raise price, suppress output, or have any other adverse effects.

While market concentration can be an important factor affecting market power, the extent to which concentration and noncompetitive behavior are correlated is far from settled, both empirically and theoretically. One stumbling block is the choice of the appropriate market concentration index.

\section{a. Approaches to Choosing an Index}

i. Axiomatic. There are two different approaches to the choice of an appropriate market concentration mdex: axiomatic and behavioral. The axiomatic approach seeks an imdex that satisfies certam axioms concerning the quantitative treatment of various collections of market shares. One such axiom, for example, is that the index reach its highest value when the imdustry is monopolized, and that it take on its lowest value when all firms im the market have equal shares. Another axiom stipulates that a merger of competitors imcrease the value of the index.

There are many concentration indexes, imcluding the familiar CR4 and CR8 (the total share of the four- and eight-largest firms, respectively), as well as the HHI, which satisfy the axioms. The actual choice of the appropriate index from this group is then an empirical matter. If econometric studies were to demonstrate that the HHI better predicts noncompetitive behavior or monopoly profits than does the CR4, then the HHI would be selected to measure market concentration for the assessment of the welfare consequences of mergers. The available empirical evidence suggests, however, that both the HHI and the CR4 per-

45. This assertion assumes that the merger will not engender strong enough efficiencies for the lowering of costs to outweigh the increase in market power. Below, we largely ignore the question of cost efficiencies created by mergers, not because we think thein unimportant, but rather because they are beyond the scope of this Article. See, however, Williamson, Vertical Merger Guidelines: Interpreting the 1982 Reforms, 71 CALIF. L. REv. 604 (1983). 
form equally well in this regard. ${ }^{46}$ One obvious reason is that these two indexes are highly correlated in the available samples of interindustry data.

ii. Behavioral. The other approach to the choice of a concentration index attempts to relate the measure to the market behavior of the incumbent firms. For example, Posner's argument that the HHI is a "more discriminatimg index of concentration" expressly relies on a behavioral presumption that the likelihood of collusive pricing is "enhanced if one or two firms are clearly dominant."47 Since the CR4 is insensitive to transfers of market share among the four leading firms, it fails to capture any increased possibility of collusion when market shares become more concentrated at the top. The HHI, on the other hand, is sensitive to redistributions of market share among all firms and, in addition, is especially sensitive to transfers of shares to "top" large firms. These are desirable features of the concentration index, given the underlymg behavioral hypothesis.

In a recent article, ${ }^{48}$ we argued that the $\mathrm{HHI}$ can be treated as a direct measure of industry performance, as measured by the percentage deviation of market price from average industry marginal cost, in certain well-defined but sharply circumscribed circumstances. The scenario im which the HHI has special economic (as opposed to arithmetic) significance is a market composed of a fixed number of noncooperative oligopolistic firms producing an identical product without inereasing returns to scale. It can be slown that here the industry-wide Lerner Index, the proportional deviation of price from marginal cost, is equal to the value of the HHI scaled down by the elasticity of market demand. It is in this and in related market scenarios that the HHI's usefulness as a ineasure of concentration is optimal.

In other market scenarios, however, other indexes of concentration may correlate better witl market performance. From the "behavioral" vantage point, therefore, the HHI emerges as a useful tool of analysis, but as one whose ability in general pre- and postmerger situations to predict by itself industry market performance may be easily overstated. Fortunately, however, there is inucli to be learned from consideration of the significant factors that the HHI fails to incorporate.

\section{b. Limitations of the $H H I$}

First of all, even where the HHI is the optimal concentration in-

46. See F. Scherer, Industrial Market Structure and Economic Performance 58 59 (2d ed. 1980).

47. Posner, Oligopoly and the Antitrust Laws: A Suggested Approach, 21 StAN. L. Rev. 1562, 1602 (1969).

48. See Ordover, Sykes \& Willig, supra note 41. 
dex, it inust be related to the value of the price elasticity of industry demand in order to ineasure the deviation of price from cost. This elasticity will be implicitly generated in the process of defining the relevant market, as described in Part $I^{49}$ It is quite unlikely that this process will define relevant markets in which the price elasticities of demand are about the same. Given this, two inergers leading to the same increase in the HHI are likely to have quite different welfare consequences in two different markets. The inerger is likely to have a inore harmful effect on social welfare if demand im the market is inelastic. ${ }^{50}$ This viewpoint is reflected in the Guidelines: "The larger the 'gap' at the edge of the product and geographic inarkets, the more likely the Departinent is to challenge the merger." 1

The second danger in placing too inuch reliance on the HHI alone is that it is a good predictor of performance only if the industry's firms behave noncooperatively. Where this description of behavior is inappropriate, the value of the HHI, even when scaled down by the appropriate elasticity of demand, may overestimate or underestimate market performance. An industry with the same $\mathrm{HHI}$ value and demand elasticity as another industry, but with less rivalrous firms than that industry, will show a higher level of monopoly profits and poorer welfare performance. It is therefore crucial in evaluating merger effects to go beyond concentration measures and examine other factors.

\section{Market Shares}

Additional critical issues concerning firms' behavior are reflected in the Guidelines' treatment of market share measurement. Four specific problems are discussed in this Subsection: choice of units, longlived commodities, capacity, and postmerger market share.

\section{a. Choice of Units}

Froin the very outset, the calculation of market shares poses the difficult problem of choice of units: Should shares be based on physical

49. See supra Part I, §§ A \& B.

50. It may be worthwhile to clarify "certain confusion that may arise at this point. On the one hand, a merger is likely to cause a larger price mcrease the less elastic is market demand, other things being equal. On the other hand, a given price increase is likely to have a more harmful effect on social welfare the inore elastic is market demand. Generally speaking, it is the former effect that predominates. This is even nore the case if the sole concern is with consumers' welfare, to the exclusion of producer's welfare (or profit). But profits should not be disregarded, accruing as they might to fully valued citizens, either directly or through such intermediaries as pension funds. However, we do not wish to minimize the equity (distributional) concerns that inay be factored into merger policy. See Coinanor \& Smiley, Monopoly and the Distribution of Wealth, 89 Q.J. ECON. 177 (1975); Kaplow, The Accuracy of Traditional Market Power Analysis and a Direct Adjustment Alternative, 95 HARv. L. REv. 1817, 1822-23 (1982).

51. Guidelines $\S \operatorname{III}(C)(1)(b), 47$ Fed. Reg. at 28,498, 71 CALIF. L. Rev. at 658. 
unit sales, dollar sales, capacity, or physical reserves? ${ }^{52}$ The Guidelines are very vague on which units should be used to compute market shares.

Which units to use in calculating share depends upon the characteristics of the relevant market. When the product market consists of a relatively honiogeneous universe of products, then physical unit sales and dollar unit sales will yield similar results. In many mergers, however, the relevant market contaims heterogeneous products-for example, cars of different quality. Then, market shares based on physical unit sales would not reflect the relative valuations consumers placed on different types of cars. Because relative prices reflect these relative valuations, sales price appears to be a better indicator. On the other hand, dollar sales data may misestimate true market power, especially where the range of product-types included in the relevant inarket is wide. For example, a car manufacturer who specializes in top quahty cars need not contribute nore to market power than a manufacturer of average quahity cars with equal unit sales but lower dollar sales. Where firms in the saine market do possess differing degrees of market power, however, their relative market shares will be influenced by its exercise. For example, a seller inay have a sinall share of physical unit sales precisely because he is restraining output in order to raise price. Then, his share of dollar sales may substantially exceed his market share based on unit sales. In this case, dollar sales would be a better indicator of his role im the market.

\section{b. Durable Goods}

The second difficulty in measuring shares arises where coinunodities are long-lived. The Guidelines state that when "recycled or reconditioned products represent good substitutes for new products," they will be included in the inarket, leading, as a result, to lower market shares for manufacturers of new products. ${ }^{53}$ This is appropriate inasmuch the ability of car manufacturers to raise prices on new models is constramed by the availability of old cars and by the ability of car owners to continue using their old cars by some additional length of time if replacement cars become more expensive. Thus, the 5\% test of market definition can still be applied to durables. The only complication is that the available stock of used goods is partly determined by previous decisions of suppliers of new goods, so that suppliers are, as it were, im competition with themselves. On these grounds, some caution in the market share treatment of used products should be exercised.

52. Id. § II(D) n.26, 47 Fed. Reg. at 28,496 n.26, 71 CALIF. L. Rev. at 654 n.26.

53. Id. $\S I I(B)(2), 47$ Fed. Reg. at 28,495, 71 CALIF. L. Rev. at 653. 
This complication is even more evident where durables are leased rather than sold. Suppliers may directly control both the flow of new products and the stock of used durables-e.g., IBM holding leases on its CPU's. The question then is whether shares ought to be calculated on the basis of the stock owned by the manufacturer or on the basis of the flow of new products. The flow-based measure is more oriented toward the future and hence may be a better predictor of the future role of the merging firms. In itself, however, the flow-based measure omits consideration of the competitive restraint on the pricing of the flow that is offered by the stock's availability. Agam, creative application of the $5 \%$ test would seem to provide an appropriate escape from this thicket.

\section{c. Capacity}

The third complication in market share calculations arises in the treatment of capacity. There are a number of difficulties im measuring capacity. ${ }^{54}$ For one thing, capacity is not a fixed datum: every factory is surely capable of working beyond its rated capacity, if the price of the product is sufficiently high to warrant it. Furthermore, not all capacity is of equal quality. Because the imvestment process goes on continuously, different firms will have different portfolios of vintages of capital equipment. These different vintages should not be treated similarly in assessing merger effects. For example, the shortrun consequences of a merger between two manufacturers wlio own state-of-theart productive capacity may be quite different from those resultimg from a merger of two manufacturers whose capital stock is outmoded.

Two approaches seem plausible for dealing with these difficulties. First, information on capacity can be treated as an additional factor to be taken into account in assessimg the importance of traditionally calculated market shares. Alternatively, an analogue of the 5\% test could be applied to existing unutilized capacity. Under this approach, currently unutilized capacity would be included in the relevant market for the purpose of calculating market shares if and only if it would be put into operation in response to a price rise of specified magnitude-for instance 5\% for at least six months or a year. The rationale for this position is clear: it is only this capacity that would serve as a competitive clieck on the pricing of the output of the currently utilized capacity. ${ }^{55}$

54. Professor Stigler defines four different methods of measuring capacity, each of which has some merit for assessing market power and merger effects. G. STIGLER, THE THEORY OF PRICE 156-58 (3d ed. 1966). For additional discussion, see Schmalensee, Another Look at Market Power, 95 HARV. L. REv. 1789, 1801 (1982). This diversity of possible methods might create nndue coinplexity and unpredictability in calcnlating capacity-based market shares.

55. This issue is most likely to arise when capacity is underutilized-an endemic condition nowadays in some industries. If capacity is fully utilized, shares based on physical output shonld be equivalent to those based directly on capacity. 
Nevertheless, one convincing reason why all capacity should be counted in market shares stems from our view of mergers as a means for coordinating the use of assets. If productive capacity is one of the assets to which inarket power attaches, then the total capacity controlled by the merging firms may be a good index of their market power now and in the future. Even unutilized capacity can be a valuable asset if it supphes credible threats of output expansion that succeed in curtailing rivals' output and driving up imdustry prices. Yet here, too, the 5\% test would, in principle, capture this effect and yield an appropriate market share partially based on capacity.

\section{d. Postmerger Market Share}

The Guidelines rely on ineasurement of values of postmerger $\mathrm{HHI}^{56}$ and on measurement of the increase in the HHI caused by a merger. ${ }^{57}$ It is clear from the context and from the details provided that in effecting these calculations, the Department will assume that the merger will leave the shares of the nonmerging firms unaltered and that the inerged firm will have a share equal to the combined shares of the merger partners. ${ }^{58}$ This assumption, however, is unwarranted and implausible as a prediction of the inerger's actual effects. Our recent theoretical research on the subject of merger incentives suggests that if a merger does not produce any efficiency gains, it is likely to reduce the market share of the merged company below the coinbined premerger shares of the inerging firms. ${ }^{59}$

In the simplest example, two firms in a symmetric three-firm oligopoly merge, and the industry becoines a symmetric duopoly. Then, the merged coinpany has a market share of $50 \%$, in contrast to the nerger partners' $67 \%$ premerger share. Here, the merger increases the HHI by 1667, from 3333 before the inerger to 5000 after the inerger. In contrast, the Guidelines' method for calculating the increase in $\mathrm{HHI}^{60}$ yields a figure of $2178(2 \times 33 \times 33)$.

Although insight can be gained from mampulation of theoretical examples of this kind (and more complex ones, as well), the fact is that accurate prediction of actual postmerger market shares from data on

56. Guidelines § III(A)(1), 47 Fed. Reg. at 28,497, 71 CALIF. L. Rev. at 656-57.

57. Id 31.

58. Id. § III(A)(1) nn. 30-31, 47 Fed. Reg. at $28,497 \mathrm{nn} \cdot 30-31,71$ CALIF. L. Rev. at $656 \mathrm{nn} .30$ -

59. This point was already noticed by Landes and Posner, supra note 24 , at $973 \&$ n.57. They even argue that froin the effect of a inerger on market share, one could deduce the rationale for the merger. Id. at 973 . Inasmuch as the needed imformation becomes available only well after the merger is consummated, it may be of little value for enforcement of the merger statute. Furthermore, the merged company may artificially maintain a high level of market share for some period of time in order to avoid a clrallenge.

60. Guidelines § III(A)(1) n.30, 47 Fed. Reg. at 28,497 n.30, 71 CALIF. L. Rev. at 656 n.30. 
premerger shares and other factors remains well beyond the capabilities of social science. Consequently, it is not our intention to take the Guidelines to task for its bright-line methods of calculation. Rather, im the interests of avoiding misunderstanding and fruitless debate, we suggest only that the Guidelines' measure be accurately relabelled as "postmerger HHI based on premerger shares."

\section{Entry Barriers}

We have thus far couched our analysis of market shares (and market power) in fairly static terms: that is, we have not yet discussed imlplications of entry for analyzing the merger's economic effccts. In this Subsection, we focus on entry barriers and expose what wc feel are the weakest links in the chain of analytical steps inhcrent in the Guidelines.

The Guidelines take the proper attitude that "if entry into a market is so easy that existing competitors could not succeed in raising price for any significant period of time," challenge of mergers is unlikcly. ${ }^{61}$ This view squares with a generally accepted notion that in a market unprotected by entry barriers, imcumbent firms cannot exercise inarket power. In such markets, which we term contestable markets, ${ }^{62}$ the threat of entry is an absolute constraint on mcumbents' markct power, there being no meaningful difference between incumbents and prospective entrants. It is for this very reason that contestable markets (much like perfectly competitive markets im more traditional approaches) serve as a useful benchmark to which actual inarkets can be compared for purposes of assessing merger effects. Indeed, we would argue that a inarket which is contestable cannot be a relevant market for merger evaluation precisely because in such a inarket, price increases are impossible and the incumbent firms cannot earn supracompetitive profits.

But most markets are not perfectly contestable, and neither are they protected by insurmountable entry barriers. Thus, the analysis of merger effects inust deal with partial or limited entry. The Guidelines contain various suggestions on low to incorporate entry into merger analysis. ${ }^{63}$

\section{a. Potential Entrants}

The Guidelines dcal with entry by assigning market shares to

61. Id. $\S \mathrm{III}(\mathrm{B}), 47$ Fed. Reg. at 28,498, 71 CALIF. L. Rev. at 657.

62. For a discussion of contestable markets, see W. Baumol, J. PANZAR \& R. WILlig, CoNTESTABLE MARKETS AND THE THEORY OF INDUSTRY STRUCTURE (1982).

63. Guidelines $\S \S \mathrm{II}(\mathrm{B})(1), \mathrm{II}(\mathrm{B}), \mathrm{IV}(\mathrm{A})(\mathrm{l})(\mathrm{b}), 47 \mathrm{Fed}$. Reg. at 28,495, 28,498, 28,499, 71 CALIF. L. REv. at $652,657,660$. 
those potential entrants whose existing facilities are currently utilized to produce other goods but can be converted cheaply and quickly. This approach, although superficially appealing, is methodologically questionable for several reasons.

i. Difficulty of Prediction. First, assigning the market shares and determining the consequences of various inethods of assignment on the market shares of the merging firms and the overall value of the $\mathrm{HHl}$ may be speculative. In particular, an analyst must predict the scale of entry that will occur and the resulting alterations in incumbents' narket shares. Thus, an analyst must ascertam whether all incuinbents will shrink uniformly, or whether those firms that are actively trying to elevate their prices will be the primary losers.

ii. Divertibility. Second, the issue of divertibility becomes critical in determining the size of possible entry through the conversion of facilities. Economists say that productive capacity is divertible when its use can be easily transformed from one product to another. For example, the barrel capacity of a Los Angeles beer brewer can be costlessly diverted froin producing beer for sale in Califorma to producing beer for shipinent to Oregon. Similiarly, the productive capacity of a chemical plant can be easily shifted from one product to another. In contrast, an assembly line at G.M. designed for Cadillacs cannot be easily diverted to the asseinbly of Chevy Vegas.

The fact that productive capacity is technically divertible at low cost, however, does not imply that all of the divertible capacity will actually be diverted froin product $A$ to product $B$ if B's price rises. The decision of how much to divert is governed by the opportunity cost of capacity diversion. This cost can rise with the quantity diverted, and can vary froin situation to situation. These inatters can be best explained with the help of a simple example.

Assnme that Stinko Chemical Products, Inc. (Stinko) has capacity to produce amiually 1 million tons of acid $A$ at a cost of $\$ 10$ per ton. This capacity can alternatively be used to produce acid B. The cost of conversion is $\$ 1$ per unit of capacity, which is ineasured in units of output, i.e., tons. Let the current price of both $A$ and $B$ be $\$ 15$ per ton. Hence, Stinko currently maximizes its profits by inanufacturing only acid $A$, and avoiding all costs of conversion.

Assuine now that as a result of an anticompetitive merger, the price of B goes up to $\$ 17$ per ton. Stinko is likely to convert some or all of its capacity to the manufacture of acid B. The opportunity cost of converting the first unit is the net revenue (or profit) forgone by diversion, e.g., $\$ 15$ (sale price of $A)-\$ 10$ (cost of producing $A)=\$ 5$. The gross profit from conversion is $\$ 17$ (sale price of $B$ ) - $\$ 10$ (cost of producing $B)-\$ 1$ (conversion cost) $=\$ 6$. Hence, Stinko will be willing to 
convert one unit of capacity. Whether Stinko would be willing to convert more depends on what happens to the prices of A and B as Stinko shifts froni manufacture of A to manufacture of B. It is likely that (1) the price of A will rise as the diversion becomes greater, so that the opportunity cost of diverting capacity will increase, and (2) the price of $B$ will fall as the diversion becomes greater, so that the profits from conversion will be falling. Consequently, it is unlikely that all of Stinko's capacity will be converted to the manufacture of acid B. ${ }^{64}$

This example demonstrates that it is the opportumity cost associated with diversion of capacity or of sales, together with the profits that can be made on the diverted sales, that determine the extent to which diversion will actually occur. Without such data, it may be difficult to determine the share of the market going to the entrants. Furthermore, the problem of how to readjust the incumbents' market shares still remains.

iii. Overestimation of Incumbents' Market Power. Third, the Guidelines' approach of assigning market share to potential entrants based on their existing facilities may lead to underestimation of the constraint that potential entrants exert on the pricing power of the incumbent firms. This issue, too, is easily illustrated by a simple exainple. Assume that the incumbent producers of burial casket knockdown parts (KD's) ${ }^{65}$ have some slight competitive advantage over possible entrants into the manufacture of KD's. Assume also that at the existing prices for casket knockdown parts, the possible entrants-for instance, firms that manufacture refrigerator doors-are essentially indifferent between entering the KD market and staying out. Thus, at the prevailing price, the incumbent firms face substantial (if not infinite) price elasticity of demand with respect to price increases. ${ }^{66}$ In other words, the incumbents' sales would decline drastically if they were to elevate prices after the inerger. Where price increases are deterred in this manner, prospective entrants significantly constrain market power.

Assume now that the analyst proceeds on the Guidelines' suggested assumption that the divertible capacity of prospective entrants is already in the market. It is now plausible to argue that the KD market participants (which now include stampers of refrigerator doors) have already reached some oligopolistic equilibrium that is unconstrained by potential entry and that merely reflects whatever concentration is

64. For a more formal discussion of this issue, see Landes \& Posner, supra note 24 , and Ordover \& Willig, supra note 24.

65. A KD is a disassembled burial casket. See Pre-Trial Brief, Gulf \& W. Indus., No. 9153 (FTC filed Aug. 27, 1982), for some additional information about this industry.

66. Given that the total demand for KD's is rather inelastic, being dependent on the mortality rate, the elasticity of demand with respect to price decreases is probably close to zero. 
inherent in their market shares. Therefore, under this assumption, the resulting market power and price are likely to be higher than in the previous instance.

This example demonstrates that incumbents' market power is overestimated by the Guidelines' approach of calculating market shares and the value of the $\mathrm{HHI}$ on the assumption that truly prospective entry has already occurred. The effectiveness of potential entry im constraining market power hes in the threat perceived by incumbents that a significant portion of their busimess imight be diverted to those prospective entrants that choose to enter. As a result, mcumbents would tend to keep prices relatively low in order to keep potential entrants out and to avoid loss of sales to actual entrants. This key effect of potential entry is essentially assumed away in the Guidelines' approach.

\section{Other Factors}

Besides market concentration, market share, and entry barriers, other factors can be crucial in evaluatimg whether a merger has anticompetitive effects. These other factors focus on more direct indicia of competitive or noncompetitive behavior. ${ }^{67}$ The Guidelines provide an extensive hist of factors that "relate to the ease and profitability of collusion. Where relevant, the factors are most likely to be important where the Department's decision whether to challenge the merger is otherwise close." 68

But what is to be made of these factors? Is it really known whether the presence of these factors signifies that a merger has more harmful effects than if the factors were not present? Consider two possible market scenarios. Market A, with concentration approaching 1600, is already performing badly because incumbent firms are tacitly colluding and the price exceeds the relevant marginal cost by a substantial margim. In market $\mathrm{B}$, competition is strong even though the HHI stands close to 1600 there as well.

It is certainly plausible that a horizontal merger will not significantly enhance the ability of firms in market A to collude, because they are already doing so. Because the merging firms cannot anticipate additional profits resultimg from a better coordination of assets, it might be inferred that the inerger is motivated by some efficiency considera-

67. An interesting approach along those lines is in Joskow, Structural Indicia: Rank-Shift Analysis as a Supplement to Concentration Ratios, 42 Rev. Econ. \& STAT. 113 (1960). See also Markovits, Predicting the Competitive Impact of Horizontal Mergers in a Monopolistically Competitive World: A Non-Market-Oriented Proposal and Critique of the Market Definition-Market ShareMarket Concentration Approach, 56 TEX. L. REv. 587 (1978).

68. See Guidelines $\S \mathrm{HI}(\mathrm{C}), 47 \mathrm{Fcd}$. Reg. at 28,498, 71 CALIF. L. Rev. at 658. 
tions. ${ }^{69}$ Conversely, in market $\mathrm{B}$, where tacit collusion is difficult, a merger can facilitate new coordination by combining the merging firms' assets and by reducing the number of firms. Thus, a merger in a rivalrous market can have inore adverse consequences than a merger im a collusive market if the former merger effects a significant change in firms' market behavior.

The issue, then, is determining the circumstances under which a horizontal inerger would be likely to alter significantly firms' behavior in the direction of more coordination and less competition. Of course, entry barriers and some degree of concentration are necessary conditions for such behavioral effects. But other factors usually thought to be conducive of coordmation (e.g., product homogeneity, availability of transaction information, and price protection clauses) may only indicate that behavior is noncompetitive both before and after a merger, while proving little about a merger's effects. Unfortunately, economics has shed virtually no light on this issue to date, in part because the issue has lieretofore not been recognized as important. ${ }^{70}$ Consequently, we can only uneasily support the Guidelines' policy of stricter enforceinent of merger policy im markets that are nore prone to collusive behavior. Of course, strict enforcement is justified when the inerger makes the market noncompetitive. But even if the market was noncoinpetitive to begin with, it can at least be argued that a inerger in a collusive market ratifies existimg coordination and reduces the chance that the market discipline will break down in the future.

\section{IV \\ Vertical Mergers}

The vertical merger section of the 1982 Guidelines differs significantly from its 1968 predecessor. The underlying reason is that, since 1968 at least, the "new learning" in the area of vertical integration has firmly established that in a variety of realistic inarket situations, vertical integration is more likely to enhance rather than to diminisl allocative efficiency. In light of this new economics, the 1982 Guidelines do not directly address concerns about the consequences of vertical mergers previously mentioned in the cases, such as "foreclosing of the com-

69. It will also be recalled that, if a group of firms is already colluding, it is likely that the relevant market will be broadly defined by the apphication of a 5\% test. Therefore, market shares will be lower than they would have been if the incumbent firms were not colluding prior to the merger.

70. However, in Ordover, Sykes \& Willig, supra note 41, and in Dansby \& Willig, Industry Performance Gradient Indexes, 69 AM. ECON. Rev. 249 (1979), we showed that an industry's welfare performance can be far more sensitive to alterations in firms' behavioral modes than to alterations in concentration alone. Also, as already mentioned, a price increase of a given size will be nore imjurious to social welfare the larger the preexisting margin between price and marginal cost. 
petitors of either party from a segment of the market otherwise open to them; . . . actual and reasonable likely adverse effects upon local industries and small businesses; . . . the existence of a trend towards vertical integration . . . in previously independent industries."71 Instead, the new Guidelines focus squarely on the horizontal effects of vertical mergers. This Part analyzes the strategic reasons for vertical mergers, and examines the situations in which horizontal effects result.

\section{A. Horizontal Effects of Vertical Mergers}

Although the Guidelines never explicitly state what is ineant by lorizontal effects of vertical mergers, these could be easily identified with adverse effects on the strength of competition that may either prevent prices froin falling or ultimately cause an increase in prices of the "downstreain" products. ${ }^{72}$ Stated differently, vertical integration inay have adverse lorizontal consequences if its primary effect is either to: (1) facilitate tacit collusion among inanufacturers; or (2) place at a competitive disadvantage present or future competitors of the vertically integrated firm. ${ }^{73}$

\section{Facilitating Collusion}

The unost obvious instance of a lorizontal effect arises when vertical integration is merely a means for facilitatimg tacit collusion, as it might be in the case of integration into the distribution stage. ${ }^{74}$ In assessing this motive for vertical imtegration, it is necessary to deterinine: (1) whether and why, in the industry in which the inerger occurs, collu-

71. These concerns and others are listed in United States Steel Corp. v. FTC, 426 F.2d 592, 599 (6th Cir. 1970).

72. In the parlance of economics, industries can be classified into upstreanı and downstream imdustries. Upstream industries supply inputs to the downstream industries. Obviously, in most instances, a price mcrease in an upstream imdustry translates soon after into a price increase of the downstream product.

73. We inust raise three caveats regarding this definition of the horizontal effects of vertical mergers: first, the initial impact of a vertical merger may be on the price of the "upstream" product and inay not be reflected in the final price for some tinue. Ultimately, however, input price increases will be passed on to consuners. Second, an incrcase in price to final consumers following a vertical merger cannot be regarded as an unambiguous signal that a nerger restrained trade. For example, a price increase could be attributed to a postmerger improvement in the quality of customer services, which might have been the maim rationale for the merger. Third, a vertical merger nuay lead to a price increase for some classes of customers and to a price decrease for other classes of custoners. In this case vertical integration is employed in order to facilitate price discrimination. Whether one should condone this effect of vertical integration is difficult to say in general. One's attitudes will depend significantly on whether one beheves that, on the average, price discrimination by profit-maximizing firms leads to aggregate improvennents in social welfare. The theoretical analyses of price discrimination are ambiguous in their assessment of wclfare effects. Schmalensee, Output and Welfare Implications of Monopolistic Third Degree Price Discrimination, 71 AM. ECON. REV. 242 (1981).

74. Guidelines § IV(B)(2), 47 Fed. Reg. at 28,501, 71 CALIF. L. REV. at 664. 
sion is easier at the distribution stage than at the manufacturing stage; (2) whether the same goal could not have been accomplished more cheaply and less obviously through some form of vertical restraints on dealers; and (3) whether detection of cheating is facilitated through vertical integration into distribution. For example, it is unlikely that cartelization is the predominant motive for vertical integration unless there already exists a comprehensive pattern of vertical imtegration by the dominant firms in the industry. Indeed, if only one firm in a highly concentrated industry integrates into distribution, this firm may be able more easily to chisel on the tacitly established cartel price.

\section{Disadvantaging Rivals}

It is somewhat less obvious how vertical integration might be used to disadvantage the existimg and prospective rivals of the vertically integrated firm and thereby adversely affect buyers of the final product. In a sense, vertical integration disadvantages rivals because it forecloses "the number of opportunities for market transactions"75 that prior to the merger were open to both the existing and potential rivals of the incumbent. The Guidelines perceive, correctly in our assessment, no anticompetitive effect merely from market foreclosure, if the part of the inarket that is thereby removed or foreclosed is inconsequential. ${ }^{76}$ Such a vertical merger, while conceivably disadvantaging a competitor (or competitors), is unlikely to harm the competitive process. The Guidelines, however, are sensitive to the possibility that if productive assets are concentrated in the primary or secondary markets, then a vertical merger can disadvantage rivals, weaken the strengths of competitive constraints, and adversely affect social welfare.

When vertical foreclosure has undesirable horizontal effects, it can be viewed as an example of the input-price mampulation strategies that can be employed by incumbent firms to disadvantage rivals and harm competition. Other forms of these strategies include restraints on vertical distribution, inanipulation of prices of complementary products needed by rivals to compete actively in the marketplace, and overpurchasing of inputs for the purpose of artificially elevating their prices. ${ }^{77}$ The hallmark of these vertical strategies is that they would not be profitable to an incumbent who engages in them but for their ad-

75. Brown Shoe Co. v. United States, 370 U.S. 294, 323-24 (1962).

76. Guidelines § IV(B)(2), 47 Fed. Reg. at 28,501, 71 CALIF. L. Rev. at 664.

77. See S. Salop \& D. Scheffman, Raising Rivals' Costs (unpublished manuscript) (forthcoming in 73 AMER. Econ. Rev. -, May 1983). See also Ordover \& Willig, An Economic Definition of Predation: Pricing and Product Innovation, 91 YALE L.J. 8 (1981); J. Ordover \& R. Willig, Notes on Non-Price Anticoinpetitive Practices by Dominant Firms (unpublished paper presented at 9th Annual Telecommunications Policy Research Conference, Annapolis Md., April 27-30, 1981). See also Schwartz \& Eisenstadt, Vertical Restraints, Economic Pohicy Office Discussion 
verse effect on rivals-present and future-leading ultimately to the enhancement of market power, and elevated prices to consuiners. ${ }^{78}$ The renainder of this Subsection relates this strategic approach to the effect on prospective and existing rivals of vertical mergers.

\section{a. Prospective Rivals}

In general, a vertical merger inay adversely affect prospective rivals if it elevates entry barriers ${ }^{79}$ - for exainple, by mcreasing the sunk portion of the requisite investinent. Entry barriers may also be raised if a vertical merger removes an efficient source of supply of the needed imput or an efficient distributor. The adverse effects of a vertical merger are not likely to materialize, however, unless the secondary market is concentrated, the vertically integrating firm already has market power over the products in the primary market, and the merger removes a substantial share of the other product froin the independent market. Indeed, the Guidelines proceed on the assumption that if after the merger "unintegrated firms in the secondary market" could serve "two minimum-efficient-scale plants in the primary market," the need for two-level entry by firms wishing to enter the primary market is not enhanced by a merger. ${ }^{80}$

\section{b. Existing Rivals}

It is somewhat less clear, perhaps, how a vertical inerger can disadvantage the existing rivals of the integrating firm. One possible market scenario mvolves a merger that reinoves froin the market an anount of an input that exceeds imternal needs of the inerger partner who buys what the other partner makes. This will disadvantage the rivals if their cost of replacing the lost quantity of the input is greater than the buyer's cost of withholding the excess quantity of the input. ${ }^{81}$ Concededly, this scenario is not likely to arise, unless perhaps the merging

Paper No. 82-8, Antitrust Division, U.S. Department of Justice (December 2, 1982), which came to our attention after this Article was completed.

78. See Ordover \& Willig, supra note 77, for an extensive discussion of the "but for" clause.

79. Guidelines § IV(B)(1), 47 Fed. Reg. at 28,500, 71 CALIF. L. Rev. at 662.

80. Id. $\S \operatorname{IV}(\mathrm{B})(1)(\mathrm{a}), 47 \mathrm{Fed}$. Reg. at 28,500,71 CALIF. L. Rev. at 662 . We should note that the empirical and theoretical grounds for this proposition are somewhat unclear, at least to us. Indeed, even with that much of a market remaining open, prospective entrants may become discouraged by a vertical merger, if for example, the removed suppliers were more efficient or were perceived to be more willing to break informal supplier arrangements with the incumbent firms and to serve the entrants. On the other hand, even if the unimtegrated market is thinned by a merger, this is not likely to have adverse effects on the probability of entry if new capacity can be installed quickly and efficiently. See id. ("sufficient unintegrated capacity").

81. An early formulation of this scenario is in Williamson, Wage Rates as a Barrier to Entry: The Pennington Case in Perspective, 82 Q.J. Econ. 85 (1968). See also S. Salop \& D. Schefiman, supra note 77 , at 3-4. 
partners' market shares are changing. In inost imstances, the inerger partners' "agreeinent" to withhold the input would be illegal, detectable, and punishable without interference with the vertical merger itself.

An additional adverse effect that a vertical nerger may have on unintegrated incumbents may arise when the inerger substantially reduces the number of firms in the open inarket, i.e., the number of independent firms. In a perfectly competitive input market, the price effect of such market thinning is likely to be nil. This is because the effect of a merger is merely to shift the input supply and deinand curves by the same amount.

When the upstream inarket is not perfectly competitive, however, narket thinning accompanied by an equivalent constriction in demand may result in an increase in the mput price. This price imcrease will have two consequences: first, the price of the final product will increase; and second, the vertically integrated firm will obtain a cost advantage over its unintegrated rivals. This cost advantage can be related to the excess of input price over its marginal cost (which equals the input's transfer price in an integrated firm). The integrated firm may be able to exploit its cost advantage over its unintegrated rivals and, in the long run, enhance its downstream market power. In either case, the efficiency gains on the cost side may be outweighed by welfare losses due to increased market power.

The dynamic effect of vertical integration that disadvantages incumbent rivals of a merging firm inay be to induce a "wave" of vertical mergers, with unintegrated firms attempting to acquire input suppliers to reduce the competitive disadvantage vis-a-vis their integrated rivals. The Guidelines do not speak of this effect, and instead take a more static or piecemeal approach to the evaluation of mergers. Although a static approach may be warranted by various enforceinent considerations, it nevertheless may fall short of an ideal. ${ }^{82}$ For example, in some situations, the cunnulative effect of a sequence of vertical inergers inay be to raise entry barriers significantly through market foreclosure. In other situations, firms that did not consummate vertical inergers when markets were relatively unconcentrated may find themselves unable to consummate efficiency-enhancing vertical mergers, while they would pass muster if the inarkets were less concentrated. These firms inay find themselves at a competitive disadvantage vis-a-vis their rivals.

\section{B. Complications of the Strategic Analysis Approach}

There is no agreement yet in the economic literature on the likeli-

82. For a stimulating discussion of these dynamic considerations in enforcement policy, see 4 P. AREeda \& D. TuRner, ANTitrust Law f 1014 (1980). 
hood that vertical mergers can be used as sophisticated nonprice anticompetitive strategies to raise the costs of the necessary products to existing and prospective rivals of a vertically imtegrating firm. Furthermore, the analysis of the effects of such strategies is further confounded because these strategies, mcluding vertical mergers, may be simultaneously inotivated by procompetitive (efficiency-enhancing) and anticompetitive considerations. For example, when a dominant firm in one market acquires its supphier, the result may be improved resource allocation if the suppher has been charging supracompetitive prices. Yet, the same acquisition may elevate entry barriers into the acquirmg markets. Paradoxically, this tension may be most pronounced when both primary and secondary markets are highly concentrated, each with, say, an HHI in excess of 1800 . Consequently, structural criteria for assessing merger effects, such as the concentration ratios and the market shares pertinent to the merging firms, are even less adequate as predictors of the anticompetitive effects of vertical mergers than they are in the case of horizontal mergers.

The difficulty in fashioning vertical merger guidelmes thus stems from the fact that unlike horizontal mergers, the anticompetitive rationales for vertical inergers are elusive and not yet fully understood. On the other hand, the procompetitive (or efficiency enhancing) motives frequently appear to be not only obvious but also compelling. Consequently, a liberal posture towards vertical mergers as reflected in the current Guidelines may seem on balance to be warranted.

Nevertheless, the literature noted in the footnotes of this Part leads to some challenging conclusions that conform with some of the conclusions reached by the "old" learning in industrial organization and antitrust. In particular, the new research generally agrees on one primciple: that vertical conduct by a firm with a protected dominant market position cannot rationally be presumed to be in the public interest. Rather, such prevalent elements of econoumic structure as inferior sources of supply (of compleinentary products), diverse consumer tastes, price inflexibilities, and rate of return constraints can lead to incentives for anticompetitive vertical conduct, such as exclusionary vertical mergers. Vertical mergers that have the effect of substantially raising the "cost of doing business" to the existing or potential rivals of the vertically integrating firm are likely to have adverse consequences for social welfare.

The 1982 Merger Guidelines do not explicitly treat vertical mergers as possible instances of exclusionary strategies with such effects. As we have seen, the Guidelines' drafters seem to work from a theoretical model that explained why and when horizontal mergers may harm coinpetition and lower social welfare. The vertical Merger Guidelines 
seem to be less firmly based on equivalent theoretical foundations. We have argued that some vertical mergers can best be analyzed as imstances of strategic intcractions among firms in interdependent markets. ${ }^{83}$ This analysis explaims the motives for anticompetitive strategic behavior and relates the investigation into inarket structure to its theoretical underpinnings.

\section{CONCLUSION}

We have surveyed the new Guidelines from the perspective of the economic theory of industrial organization, focusing on the question whether scrutimy of mergers that follows the Guidelines will reliably identify those mergers with anticompetitive effects. For horizontal mergers, our short answer is yes, althougl inevitably a few caveats are necessary.

The key to the Guidelines is its conceptual framework for market definition. We find this framework to be significantly consistent with economic learning and helpful for logically resolving otherwise difficult issues involved in delineating relevant product and geographic markets. Indeed, the Guidelines solve previously unsolved problems of geographic market definition by unifying their treatment, at the conceptual level, with that of product market definition. Our principal caveat here relates to the Guidelines' conscious exclusion of entry considerations in defining markets, although entry effects are considered in other stages of the prescribed analysis.

The Guidelines lay out methods for answering whether conditions of concentration, supply response, and firm conduct are likely to render benign the effects of a horizontal merger. While necessarily imperfect, these methods are consistent with known lessons of economic theory. Further, it seems that inost of these inethods could not be obviously and generally improved upon, except with detailed economic analysis that is specific to the case at hand and that requires substantially more data than presumed available by the Guidelines. Here too, however, we think that the Guidelines somewhat understate the possible restraining effects of potential entry. And, like state of the art economic theory, the Guidelines remain too silent on the interactive effects of concentration and firm behavior.

In the area of vertical mergers, the new Guidelines are inuch superior on balance to their predecessors, and their focus on horizontal effects is an appropriate analytic framework. However, the Guidelines suffer froin the absence of an underlying set of principles for vertical mergers that is as mcisive as that which inforns the prescribed analysis

83. See supra note 77. 
of horizontal mergers. Although the economic literature on vertical mergers also remains unsettled on these matters, one useful general principle seems to be ennerging: vertical mergers that have the primary effect of substantially raismg rivals' costs of doing business are likely to harin social welfare. Thus, we think there is room for improving the Guidelines by incorporating methods of vertical merger analysis based on this principle.

We feel that the new Guidelines take a highly significant step towards an effective merger policy that protects competition and promotes social welfare. In addition, because the Guidelines define a rational policy, they will stimulate further developments im their evolution that can only improve the social productivity of the United States antitrust efforts. 